not organized, and therefore, there is no need for a "high powered" system.

The results in the treatment of embolized material showed that this system can be applied before balloon angioplasty, but it can also be a very useful tool during an interventional procedure when fresh thrombus has embolized. In the latter situation, the balloon catheter can easily be exchanged for the Rescue PT catheter because of the monorail system to perform distal thrombosuction.

Angiographic analysis showed that distal flow was restored in 41 of the 51 vessels with thrombectomy alone, but the operator decided to perform an additional procedure because of residual lesions in 42 of the vessels $(83 \%)$. This percentage is comparable with the trials using other thrombectomy devices, probably because most operators do not accept a good distal runoff alone but also want to achieve an optimal angiographic result. Although stents were only placed in 18 lesions and no patient received a glycoprotein IIB/IIIA receptor antagonist, even when patients were not pretreated with a thrombolytic agent, only 4 patients underwent target vessel revascularization during 6-month follow-up ( 2 percutaneous interventions after 1 hour and after 1 day, respectively, 2 bypass operations after hospital discharge).

Despite the limited number of patients, this study showed that thrombosuction using the Rescue PT catheter is safe and effective in patients with a fresh thrombus of $<10$ hours old in native coronary arteries as well as in older venous bypass grafts. An additional important finding was that material embolized during passage of the guidewire or after balloon angioplasty could be successfully removed from distal vessels.

The Rescue PT device is an intuitive, fast, safe, and effective alternative for the removal of fresh thrombus from coronary arteries and bypass grafts during interventional procedures to prevent reclosure and distal embolization. It is also particularly useful for the management of embolized material.

1. The GUSTO Investigators. An interventional randomized trial comparing four thrombolytic strategies for acute myocardial infarction. N Engl J Med 1993;328: $673-682$.

2. Lee KL, Woodlief LH, Weaver WD, Betriu A, Simons M, Aylward P, Van de Werf F, Califf RM, for the GUSTO-I Investigators. Predictors of 30-day mortality in the era of reperfusion for acute myocardial infarction: results from an international trial of 41021 patients. Circulation 1995;91:1659-1668.

3. ISIS-2 (Second International Study of Infarct Survival) Collaborative Group. Randomized trial of intravenous streptokinase, oral aspirin, both, or neither among 17187 cases of suspected acute myocardial infarction: ISIS-2. Lancet $1988 ; 2: 349-402$.

4. Gibbons RJ, Holmes DR, Reeder GS, Leon MB, Rothbaum DA, Cummins FE Goldenberg T, Bresnanan JF. Immediate angioplasty compared with the administration of a thrombolytic agent followed by conservative treatment for myocardial infarction. N Engl J Med 1993;328:685-691.

5. Grines CL, Browne KF, Marco J, Rothbaum D, Stone GW, O'Keefe J, Overlie P, Donohue B, Chelliah N, Timmis GC. A comparison of immediate coronary angioplasty with intravenous streptokinase for acute myocardial infarction. N Engl J Med 1993;328:673-679.

6. Zijlstra F, De Boer MJ, Hoorntje JCA, Reiffers S, Reiber JH, Suryapranata H. A comparison of immediate coronary angioplasty with intravenous streptokinase in acute myocardial infarction. N Engl J Med 1993;328:680-684.

7. Chesebro JH, Knatterud G, Roberts R, Borer J, Cohen LS, Dodge HT, Francis CK, Hillis D, Ludbrook P. Thrombolysis in myocardial infarction (TIMI) trial, phase I: a comparison between intravenous tissue plasminogen activator and intravenous streptokinase. Circulation 1987;76:142-154.

8. Kaplan BM, Larkin T, Safian RD, O’Niell WW, Kramer B, Hoffmann M, Schreiber T, Grines CL. Prospective study of extraction atherectomy in patients with acute myocardial infarction. Am J Cardiol 1996;78:383-388.

9. Nagakawa Y, Matsuo S, Kimura T, Yokoi H, Tamura T, Hamasaki N, Nosaka $\mathrm{H}$, Nobbuyoshi M. Thrombectomy with the AngioJet catheter in native coronary arteries for patients with acute or recent myocardial infarction. Am J Cardiol 1999;83:994-999.

10. van Ommen GV, van den Bos AA, Pieper M, den Heyer P, Thomas MR, Ozbeck S, Bär FW, Wellens HJ. Removal of thrombus from aortocoronary bypass grafts and coronary arteries using the 6Fr Hydrolyser. Am J Cardiol 1997;79:1012-1016.

11. Rosenschein U, Roth A, Rassin T, Basan S, Miller HI. Analysis of coronary ultrasound thrombolysis endpoints in myocardial infarction (Acute Trial). Results of the feasibility phase. Circulation 1997;95:1411-1416.

12. Hamm C, Steffen W, Terres W, de Scheerder I, Reimers J, Cumberland D, Siegel RJ, Meinertz T. Intravascular ultrasound thrombolysis in acute myocardial infarction. Am J Cardiol 1997;80:200-204.

13. Reisman M, Dewhurst TA, DeVore LJ. A new percutaneous thrombectomy catheter: an investigational report. Circulation 1996;94:I-618.

\title{
Predictors of Restenosis Following Unprotected Left Main Coronary Stenting
}

\author{
José Suárez de Lezo, MD, Alfonso Medina, MD, Miguel Romero, MD, \\ Enrique Hernández, MD, Manuel Pan, MD, Antonio Delgado, MD, José Segura, MD, \\ Diordje Pavlovic, MD, and Fernando Wanguemert, MD
}

$\mathbf{U}$ nprotected left main (LM) coronary artery disease has a wide spectrum of clinical presentations and risks. ${ }^{1}$ Once identified, selection of percutaneous or surgical management remains controversial. Unprotected LM coronary lesions may be managed

\footnotetext{
From the Hospital Reina Sofía, University of Córdoba, Córdoba; and Hospital Dr. Negrín, University of Las Palmas, Las Palmas de Gran Canaria, Spain. Dr. Suárez de Lezo's address is: Servicio de Cardiología, Hospital Reina Sofía, Avda. Menéndez Pidal s/n, 14004 Córdoba, Spain. E-mail: grupo_corpal@arrakis.es. Manuscript received December 19, 2000; revised manuscript received and accepted March 8, 2001
}

safely with intracoronary stent therapy, ${ }^{2-6}$ although strategies for different anatomic subsets may vary. However, late restenosis remains the main limitation. The identification of patients at higher risk of late restenosis at this specific site might improve selection for treatment. This report is a retrospective study focused on the factors influencing restenosis after unprotected LM coronary stenting.

From a total of 155 patiens with unprotected LM coronary disease who received stents, we selected those who had primary success and favorable in- 


\begin{tabular}{|c|c|c|}
\hline & $\begin{array}{l}\text { Study Group } \\
(\mathrm{n}=77)\end{array}$ & $\begin{array}{l}\text { Overall Series } \\
(n=155)\end{array}$ \\
\hline \multicolumn{3}{|l|}{ Clinical } \\
\hline Age (yrs) & $58 \pm 10^{*}$ & $63 \pm 11^{*}$ \\
\hline Men (\%) & $58(75 \%)$ & 117 (75\%) \\
\hline Stable angina pectoris & $16(21 \%)$ & 27 (17\%) \\
\hline Unstable angina pectoris & $58(75 \%)$ & $122(69 \%)$ \\
\hline AMI in cardiogenic shock & $3(4 \%)$ & $6(4 \%)$ \\
\hline \multicolumn{3}{|l|}{ Angiographic } \\
\hline \multicolumn{3}{|l|}{ LM lesion location } \\
\hline Ostial & $18(23 \%)$ & $48(31 \%)$ \\
\hline Body & $14(18 \%)$ & $24(15 \%)$ \\
\hline Bifurcation & 45 (58\%) & $83(54 \%)$ \\
\hline No. stents/patient & $2.2 \pm 1.1$ & $2.2 \pm 1.3$ \\
\hline Stented length $(\mathrm{mm})$ & $18 \pm 12$ & $17 \pm 13$ \\
\hline Stent diameter $(\mathrm{mm})$ & $3.6 \pm 0.4$ & $3.7 \pm 0.4$ \\
\hline Stenting at remote sites & $57(74 \%)$ & $111(72 \%)$ \\
\hline $\begin{array}{l}\text { Need for cardiopulmonary } \\
\text { support }\end{array}$ & $28(36 \%)$ & $41(26 \%)$ \\
\hline \multicolumn{3}{|l|}{ Results } \\
\hline Primary success & - & $142(92 \%)$ \\
\hline In-hospital mortality & - & $5(3 \%)$ \\
\hline AMl & - & $8(5 \%)$ \\
\hline Angiographic reevaluation & - & $77(50 \%)$ \\
\hline Restenosis rate & $26(34 \%)$ & - \\
\hline Target lesion revascularization & $26(34 \%)^{*}$ & $26(17 \%)^{*}$ \\
\hline $\begin{array}{l}{ }^{*} p<0.05 . \\
A M I=\text { acute myocardial infarction. }\end{array}$ & & \\
\hline
\end{tabular}

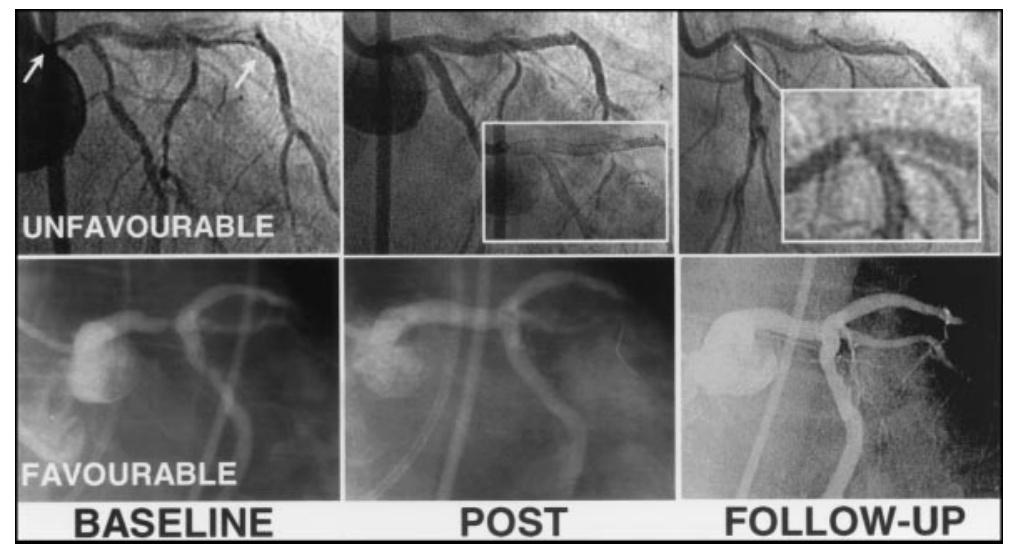

FIGURE 1. Serial angiographic observations of the left coronary artery (right anterior oblique projection) in $\mathbf{2}$ different patients at baseline, after stent treatment, and at follow-up. Upper panels, critical restenosis of the LM site at follow-up was influenced by the combination of unfavorable baseline conditions, such as diffuse disease in the whole proximal left coronary artery (arrows) and a short LM artery. This led to complete stent reconstruction of the bifurcation. Lower panels, late angiographic success was determined by a favorable acute condition, such as a single lesion located in the body of a long LM lesion close to a trifurcation. This led to the implantation of a short stent adjusted to the oufflow ostia.

hospital outcome $(\mathrm{n}=142)$, and also had serial angiographic observations $(n=77)$ (before treatment, immediately after stent placement, and at follow-up). This group of 77 patients formed the study cohort. All patients had successful stent implantation at the LM site, and 57 patients (74\%) had successful implantation at other remote sites, all with a favorable inhospital outcome. Table 1 shows baseline data in comparison with the overall series. Right and left cardiac catheterization were performed in all patients. After angiographic assessment of left ventricular function and the coronary arteries, the ideal projection that showed the LM anatomy most clearly was selected for analysis. In 28 patients the procedure was monitored by intracoronary ultrasound studies. After angiographic and ultrasonic measurements, a strategy was designed for each patient, according to the anatomy of the LM lesion, the site and characteristics of the LM plaque, the presence of remote lesions needing repair, and hemodynamic condition. Standby cardiopulmonary support was available for all patients and was instituted when hemodynamic instability occurred before or during the procedure. Once stent treatment was completed, all patients under cardiopulmonary support were easily weaned from the pump; 7 patients required inotropic drugs. In patients with involvement of the bifurcation, 2 guidewires were passed into the left anterior descending and left circumflex arteries, respectively. In patients without bifurcation involvement, a single wire was placed in the left anterior descending artery. As in other bifurcation lesions, stent treatment was initially designed according to a stepwise strategy, from the simplest stent oriented to the left anterior descending artery to the most complexed stent reconstruction of the bifurcation. ${ }^{7}$

In patients with combined right coronary artery disease, representing the highest myocardium at risk, the right coronary artery was first revascularized, before attempting the $\mathrm{LM}$ site. The stent diameter and length were selected in accordance with on-line quantitative coronary angiography and/or intracoronary ultrasonography meassurements. Stents were deployed at the LM site at a mean pressure of $13 \pm$ 2 atm. All patients were discharged asymptomatic, $2 \pm 2$ days after treatment, and received antithrombotic therapy (lowmolecular weight heparin, ticlopidine or clopidogrel, and aspirin) for 1 month. All 77 patients underwent follow-up cardiac catheterization after $9 \pm 9$ months; 26 of them had restenosis ( $>50 \%$ stenosis) at the LM site and 51 had continuing success. Patients with restenosis of the LM sites or at other sites underwent percutaneous intervention (14 cases) or surgery (12 cases).

Factors influencing restenosis at the LM site were studied. Quantitative data are expressed as mean \pm SD. Comparison between restenosis and late success was performed by Student's $t$ test for continuous and chi-square test for categorical variables. Those factors showing significant $p$ values were included in a multivariate stepwise logistic regression model (SPSS software, SPSS Inc., Chicago, Illinois).

Figure 1 shows 2 examples of different angiographic evolution after treatment. Tables 2 and 3 show the univariate study. A small LM diameter, the bifurcational involvement of the lesion, and the need for a longer stented length were adverse factors in the uni- 


\begin{tabular}{|lcc|}
\hline TABLE 2 Clinical Factors & & \\
\hline & $\begin{array}{c}\text { Restenosis } \\
(\mathrm{n}=26)\end{array}$ & $\begin{array}{c}\text { Late Success } \\
(\mathrm{n}=51)\end{array}$ \\
\hline Age (yrs) & $58 \pm 13$ & $59 \pm 9$ \\
Men (\%) & $18(69 \%)$ & $40(78 \%)$ \\
Previous myocardial infarction & $6(23 \%)$ & $12(24 \%)$ \\
Stable angina pectoris & $3(12 \%)$ & $13(25 \%)$ \\
Unstable angina pectoris & $22(85 \%)$ & $36(71 \%)$ \\
AMl in cardiogenic shock & $1(4 \%)$ & $2(4 \%)$ \\
Diabetes & $6(23 \%)$ & $12(24 \%)$ \\
Hyperlipemia* & $12(46 \%)$ & $21(48 \%)$ \\
Systemic hypertension & $16(62 \%)$ & $24(47 \%)$ \\
Smoking & $11(42 \%)$ & $25(52 \%)$ \\
\hline *Total cholesterol $\geq 220 \mathrm{mg} / \mathrm{dl}$. & & \\
Abbreviation as in Table 1. & & \\
\hline
\end{tabular}

TABLE 3 Angiographic, Procedural, and Ultrasonic Data

\begin{tabular}{|c|c|c|c|}
\hline & $\begin{array}{l}\text { Restenosis } \\
(\mathrm{n}=26)\end{array}$ & $\begin{array}{l}\text { Late Success } \\
(\mathrm{n}=51)\end{array}$ & $\begin{array}{c}\mathrm{p} \\
\text { Value }\end{array}$ \\
\hline Ejection fraction (\%) & $64 \pm 13$ & $61 \pm 11$ & NS \\
\hline LM length (mm) & $13 \pm 5$ & $18 \pm 9$ & 0.01 \\
\hline $\begin{array}{l}\text { Reference LM diameter } \\
\quad(\mathrm{mm})\end{array}$ & $3.56 \pm 0.4$ & $3.94 \pm 0.4$ & 0.01 \\
\hline Lesion length $(\mathrm{mm})$ & $16 \pm 15$ & $8 \pm 4$ & 0.05 \\
\hline MLD pre (mm) & $1.07 \pm 0.7$ & $1.08 \pm 0.6$ & NS \\
\hline MLD post (mm) & $3.31 \pm 0.5$ & $3.54 \pm 0.6$ & NS \\
\hline Percent stenosis & $71 \pm 17$ & $73 \pm 12$ & NS \\
\hline Lesion location & & & 0.05 \\
\hline Ostial & 5 & 13 & \\
\hline Body & 1 & 13 & \\
\hline Bifurcation & 20 & 25 & \\
\hline Stent diameter $(\mathrm{mm})$ & $3.49 \pm 0.4$ & $3.65 \pm 0.4$ & NS \\
\hline Stenting at remote sites & $14(67 \%)$ & $24(63 \%)$ & NS \\
\hline $\begin{array}{l}\text { Deployment pressure } \\
\text { (atm) }\end{array}$ & $13 \pm 2$ & $13 \pm 2$ & NS \\
\hline Type of plaque & & & NS \\
\hline Echogenic & 4 & 4 & \\
\hline Echolucent & 4 & 5 & \\
\hline Mixed & 4 & 7 & \\
\hline Coronary calcium & 8 & 11 & NS \\
\hline IVUS stent diameter & $3.63 \pm 0.6$ & $3.79 \pm 0.5$ & \\
\hline
\end{tabular}

variate analysis. In addition, the longer the length of the LM artery and the shorter the lesion length within the main stem, the lower the restenosis rate at followup. These last 2 are independent predictors of restenosis at this specific site (Figure 2).

Stent treatment of unprotected LM coronary disease is feasible and safe in most patients. ${ }^{2-6}$ However, restenosis at this specific site still remains the main limitation. This study is characterized by a wide spectrum of clinical and anatomic substrates, all of them considered to be potential factors influencing restenosis. The anatomic location of the lesion at the LM stem could play an important role. In our series, $>50 \%$ of the patients had the LM lesion involving the bifurcation, which could increase the complexity of the procedure. In fact, all bifurcation lesions can be treated with stents with a high rate of initial success,

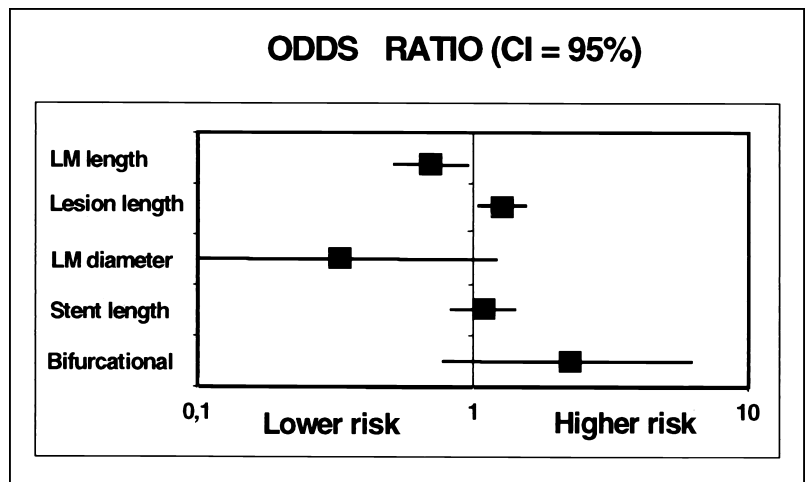

FIGURE 2. Factors influencing restenosis after unprotected LM coronary stenting (multivariate analysis). $\mathrm{Cl}=$ confidence interval.

but with different rates of long-term results. A stepwise strategy is recomended to improve late outcome, ${ }^{7}$ which seems to apply to the LM bifurcation. In contrast, lesions located at the ostium or the body are easy to treat with stents, especially in patients with long LM arteries; these factors are associated with better long-term results (Table 3). Predictors of restenosis after stent treatment of unprotected LM coronary disease have not been studied in detail and there is only one recent study ${ }^{5}$ that comments on them. Our findings show that short lesions located at the LM are associated with low risk of restenosis after stent therapy. In addition, the longer the LM artery, the lower the probability of restenosis after stent placement. Other adverse factors are a bifurcation involvement, a smaller reference diameter, and the need for longer stent covering.

In conclusion, the whole clinical and anatomic spectrum of LM coronary disease can be treated safely with stents; however, short lesions and long stems are independent predictors for better longterm results.

1. Caracciolo EA, Davis KB, Sopko G, Kaiser GC, Corley SD, Schaff H, Taylor HA, Chaitman BR. Comparison of surgical and medical group survival in patients with left main coronary artery disease. Long-term CASS experience. Circulation 1995;91:2325-2334.

2. Park SJ, Park SW, Hong MK, Cheong SS, Lee CW, Kim JJ, Hong MK, Mintz GS, Leon MB. Stenting of unprotected left main coronary artery stenoses: immediate and late outcomes. J Am Coll Cardiol 1998;31:37-42.

3. Laruelle CJ, Brueren GB, Ernst SM, Bal ET, Mast GE, Suttorp MJ, Brutel de la Riviere A, Plokker TH. Stenting of "unprotected" left main coronary artery stenoses: early and late results. Heart 1998;79:148-152.

4. Hong MK, Park SW, Lee CW, Kang DH, Song JK, Kim JJ, Park SJ, Hong MK, Mintz GS, Leon MB. Intravascular ultrasound findings in stenting of unprotected left main coronary artery stenosis. Am J Cardiol 1998;82:670-673.

5. Marso SP, Steg G, Plokker T, Holmes D, Park SJ, Kosuga K, Tamai H, Macaya C, Moses J, White H, Verstraete SF, Ellis SG. Catheter-based reperfusion of unprotected left main stenosis during an acute myocardial infarction (the ULTIMA experience). Unprotected Left Main Trunk Intervention Multi-center Assessment. Am J Cardiol 1999;83:1513-1517.

6. Silvestri M, Barragan P, Sainsous J, Bayet G, Simeoni JB, Roquebert PO, Macaluso G, Bouvier JL, Comet B. Unprotected left main coronary artery stenting: immediate and medium-term outcomes of 140 elective procedures. $J$ Am Coll Cardiol 2000;35:1543-1550.

7. Pan M, Suárez de Lezo J, Medina A, Romero M, Hernández E, Segura J, Castroviejo JR, Pavlovic DJ, Melián F, Ramírez A, Castillo JC. Simple and complex stent strategies for bifurcated coronary arterial stenosis involving the side branch origin. Am J Cardiol 1999;83:1320-1325. 